\title{
Concurrent central retinal artery occlusion and branch retinal vein occlusion in giant cell arteritis
}

\author{
This article was published in the following Dove Press journal: \\ Clinical Ophthalmology \\ 24 June 2010 \\ Number of times this article has been viewed
}

\section{Edward R Chu \\ Celia S Chen}

Department of Ophthalmology, Flinders Medical Centre and Flinders University, Bedford Park, SA, Australia
Correspondence: Celia S Chen Department of Ophthalmology, Flinders Medical Centre, Flinders Drive, Bedford Park, South Australia, 5042, Australia Tel +6I 882044899

Fax +6I 882770899

Email celia.chen@health.sa.gov.au

\begin{abstract}
Ophthalmic involvement in giant cell arteritis can manifest in a number of ways. Central retinal artery occlusion is one of the common causes of visual loss in giant cell arteritis. On the contrary, branch retinal vein occlusion is rarely associated with the latter. We report an 89-yearold lady with acute left central retinal artery occlusion on a background of progressive decline in vision over a 6-month period with a concurrent right branch retinal vein occlusion. Subsequent investigation confirmed giant cell arteritis on temporal artery biopsy. This is the first reported case of a concurrent central retinal artery occlusion and branch retinal vein occlusion in giant cell arteritis, and highlights the various ocular presentations that can occur in giant cell arteritis.
\end{abstract}

Keywords: giant cell arteritis, retinal artery occlusion, retinal vein occlusion

\section{Case report}

An 89-year-old lady presented with an acute painless loss of vision in the left eye on a background of progressive decline of vision over a 6-month period. Further history revealed a 6-month history of mild headache, lethargy, and jaw claudication, which she put down to the 'flu'. Her pertinent past medical history included controlled hypertension since 1996 with mean arterial pressure of $110 \mathrm{mmHg}$. She has peripheral vascular disease with claudication after walking 100 meters but did not require vascular intervention. On examination, her best-corrected visual acuity was 20/40 OD and hand movement OS. There was a left relative afferent pupillary defect associated with recognition of gross color only in the left eye. Neuro-ophthalmic examination showed normal extraocular motility and cranial nerves. There was no scalp tenderness. Her left temporal artery was prominent and firm to palpate, however, the pulse was impalpable. Anterior segments revealed bilateral nuclear sclerotic cataracts. Fundoscopy of the right eye revealed hemorrhage in the superior temporal quadrant suggestive of branch retinal vein occlusion (BRVO) as shown in Figure 1A. This was confirmed with fundus fluorescein angiography. The left eye revealed an acute central retinal artery occlusion (CRAO) with retinal infarction and cherry red spot. Red free photographs of both fundi are seen in Figure 1B. Fundus fluorescein angiography of the left eye revealed retinal arterial attenuation from CRAO as well as patchy choroidal filling defect with delayed retrograde filling suggesting medial posterior ciliary artery occlusion with the CRAO (Figure 2). Investigation into the cause of the CRAO revealed an acute rise in inflammatory markers including an elevated erythrocyte sedimentation rate of $101 \mathrm{~mm} / \mathrm{hr}$. Thrombophilia markers were 




Figure I A) Colored fundus photograph of the right and left eye. The right eye revealed a superior temporal branch retinal vein occlusion (arrow) showing multiple hemorrhages (arrowheads). The left eye showed an acute central retinal artery occlusion (cherry red spot (C) and marked arteriole attenuation with pale retina in comparison to the right eye). B) Red free photograph of the corresponding fundus illustrating the site of the branch retinal vein occlusion (arrow) and hemorrhages in the right eye (arrowhead).

negative. She was managed with a stat dose of methylprednisolone $1 \mathrm{~g}$ intravenously followed by oral prednisolone at 1 $\mathrm{mg} / \mathrm{kg}$. A left temporal artery biopsy was performed within 2 days and histopathology was consistent with GCA associated with intimal hyperplasia and luminal narrowing.

\section{Discussion}

To our knowledge, this is the first reported case of concurrent CRAO and BRVO in an elderly lady with GCA. Among a wide variety of ophthalmic manifestations of GCA, CRAO is the second most common cause of GCA-related visual loss after

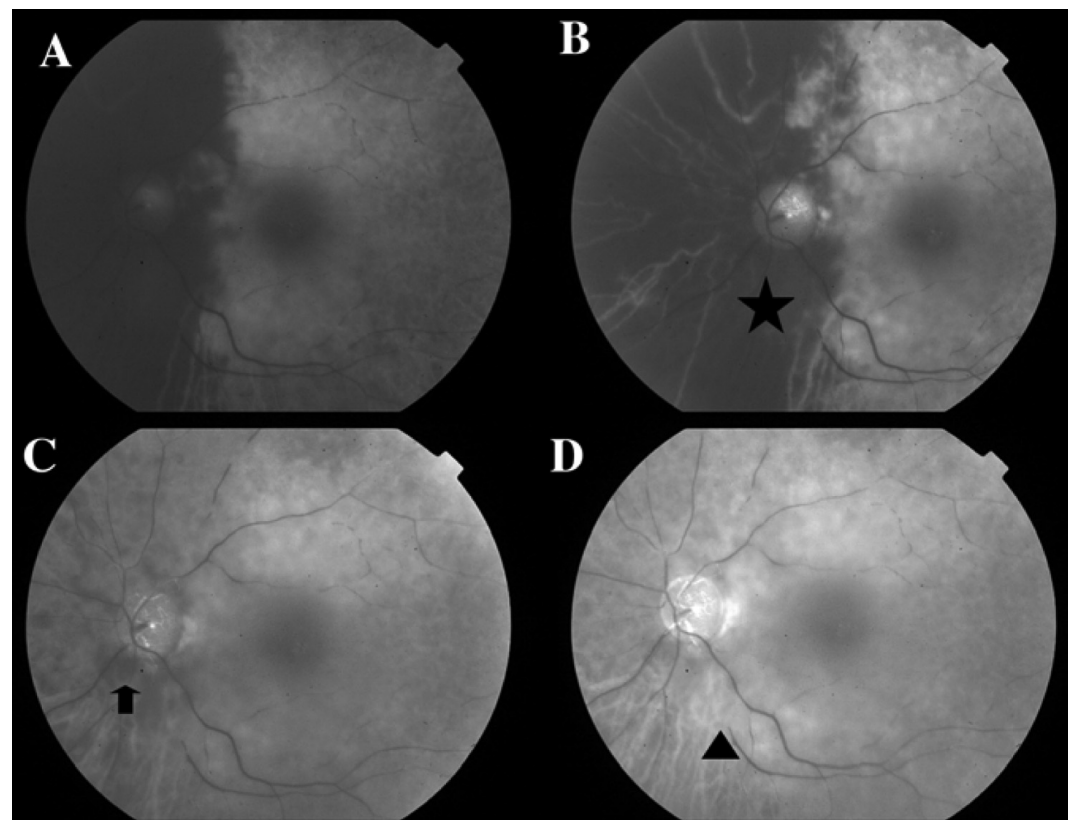

Figure 2 Fundus fluorescein angiography of the left eye at (A) 25 seconds, (B) 49 seconds, (C) one minute 56 seconds, and (D) 5 minutes I4 seconds that revealed nasal choroidal filling defect (star), delayed retrograde filling (arrow), and arterial attenuation (arrowhead). 
anterior ischemic optic neuropathy. ${ }^{1}$ However, a relationship between retinal vein occlusion and GCA is rare. ${ }^{2}$

BRVO is associated with certain diseases that include hypertension and peripheral vascular disease, which are both present as medical co-morbidities of this patient. The suggested main mechanism of BRVO is trophic changes in the venous endothelium and intima media at the arteriovenous (AV) crossing. ${ }^{3}$ Furthermore, the patient's medical co-morbidities are associated with the development of retinal artery sclerosis. ${ }^{3}$ At the AV crossing, the retinal artery and vein share one adventitial sheath. ${ }^{3}$ With the increasing rigidity of the arterial wall secondary to sclerotic artery, contraction of the adventitial sheath occurs resulting in venous compression. ${ }^{3}$ The compressed vein leads to turbulent blood flow through the AV crossing, damaging the venous endothelium and intimamedia. The combined effects of trophic changes and turbulent blood flow can potentially result in thrombus formation and subsequent venous occlusion.

The above hemodynamic compromises from BRVO can be exacerbated in the presence of GCA. The arteritic inflammation in GCA can alter the endothelium and result in accelerated atherosclerosis. ${ }^{4}$ This can contribute to the development of venous occlusion by further aggravating an already compromised venous environment. As GCA and vascular risk factors tend to occur more commonly in the elderly, BRVO can be an atypical presentation of GCA in this patient. Hence, in patients with retinal vein occlusion with no or minimal attributable cause, it has been suggested that GCA should be considered in the differential diagnosis. ${ }^{2}$ In conclusion, patients with GCA can present with concurrent CRAO and BRVO.

\section{Disclosure}

The authors report no conflicts of interest in this work.

\section{References}

1. Kawasaki A, Purvin V. Giant cell arteritis: an updated review. Acta Ophthalmol. 2009;87(1):13-32.

2. Zaldivar RA, Calamia KT, Bolling JP. Retinal vein occlusion in giant cell arteritis [abstract]. Invest Ophthalmol Vis Sci. 2004;45:1589.

3. Rehak J, Rehak M. Branch retinal vein occlusion: pathogenesis, visual prognosis and treatment modalities. Curr Eye Res. 2008;33(22): $111-131$.

4. Gonzalez-Juanatey C, Llorca J, Garcia-Porrua C, Sanchez-Andrade A, Martín J, Gonzalez-Gay MA. Steroid therapy improves endothelial function in patients with biopsy-proven giant cell arteritis. J Rheumatol. 2006;33(1):74-78.
Clinical Ophthalmology

\section{Publish your work in this journal}

Clinical Ophthalmology is an international, peer-reviewed journal covering all subspecialties within ophthalmology. Key topics include: Optometry; Visual science; Pharmacology and drug therapy in eye diseases; Basic Sciences; Primary and Secondary eye care; Patien Safety and Quality of Care Improvements. This journal is indexed on

Submit your manuscript here: http://www.dovepress.com/clinical-ophthalmology-journal

\section{Dovepress}

PubMed Central and CAS, and is the official journal of The Society of Clinical Ophthalmology (SCO). The manuscript management system is completely online and includes a very quick and fair peer-review system, which is all easy to use. Visit http://www.dovepress.com/ testimonials.php to read real quotes from published authors. 